Summer 2014

\title{
A Trail to Modernity: Observations on the New Developments of China's Evidence Legislation Movement in a Global Context
}

Jia Li

Indiana University Maurer School of Law, Jia.LiContact@gmail.com

Zhuhao Wang

China University of Political Science and Law., wangzhuhao@gmail.com

Follow this and additional works at: https://www.repository.law.indiana.edu/ijgls

Part of the Comparative and Foreign Law Commons, Evidence Commons, International Law Commons, and the Legislation Commons

\section{Recommended Citation}

$\mathrm{Li}$, Jia and Wang, Zhuhao (2014) "A Trail to Modernity: Observations on the New Developments of China's Evidence Legislation Movement in a Global Context," Indiana Journal of Global Legal Studies: Vol. 21 : Iss. 2 , Article 12.

Available at: https://www.repository.law.indiana.edu/ijgls/vol21/iss2/12

This Note is brought to you for free and open access by the Law School Journals at Digital Repository @ Maurer Law. It has been accepted for inclusion in Indiana Journal of Global Legal Studies by an authorized editor of Digital Repository@Maurer Law. For more information, please contactrvaughan@indiana.edu.

\section{$\Psi$}

JEROME HALL LAW LIBRARY

INDIANA UNIVERSITY

Maurer School of Law
Bloomington 


\title{
A Trail to Modernity: Observations on the New Developments of China's Evidence Legislation Movement in a Global Context
}

\author{
JIA LI* \& ZHUHAO WANG*
}

\begin{abstract}
China, like most other civil law countries, does not have a discrete evidence code. Rather, Chinese evidence rules are currently scattered among various procedural codes. Since the beginning of the twenty-first century, Chinese scholars and practitioners have advocated for specialized evidence legislation. As part of this movement, China issued numerous judicial interpretations of evidence law, amendments to existing procedural law, and experimental drafts of evidence statutes. For example, new amendments to the Civil Procedure Law and to the Criminal Procedure Law became effective on January 1, 2013. More recently, the Supreme People's Court led the efforts to create two experimental drafts of judicial interpretations for evidence rules, namely the "People's Courts Uniform Provisions of Evidence of the People's Courts" in 2008 and the "People's Courts Provisions of Evidence in Litigation" in 2012. Both drafts contemplate the ultimate adoption of a comprehensive evidence statute into the Chinese law. Both drafts contain hallmarks of evidence law, including terminology, methodology, and legal principles, that are regularly seen in the common law system. Yet

* Jia $\mathrm{Li}$ (李嘉), licensed to practice law in the State of New York and the State of Indiana, and qualified to practice law in China; Editor-in-Chief, Indiana Journal of Global Legal Studies; J.D., 2014, Indiana University Maurer School of Law. Jia would like to express her deep appreciation to Prof. Alfred C. Aman and Prof. Aviva A. Orenstein for their invaluable insights and guidance, and to the editorial team of the Indiana Journal of Global Legal Studies for all the hard work. She would also like to extend her special gratitude to her family for their unfailing support and encouragement.

** Zhuhao Wang (汪诸蒙), Fellow, Collaborative Innovation Center of Judicial Civilization, China; Assistant Professor, Institute of Evidence Law and Forensic Science, China University of Political Science and Law. This article is interim research work for the China Ministry of Education (MOE) Research Project of Humanities and Social Sciences-2013 Young Scholar Support Program "Studies on Impeachment System" (Project No.13YJC820073).
\end{abstract}

Indiana Journal of Global Legal Studies Vol. 21 \#2 (Summer 2014)

(C) Indiana University Maurer School of Law 
both drafts retain characteristics of the Chinese legal system and Chinese cultural traditions. The authors analyze the latest developments in China's evidence legislation movement and observe that China's recent experience demonstrates a process of modernization.

\section{INTRODUCTION}

Although the concept of codification originated in the civil law system, ${ }^{1}$ most civil law countries do not appear interested in creating a statute specifically for evidence. ${ }^{2}$ Rather, in most civil law countries, the rules governing evidence are typically scattered among various procedural statutes. ${ }^{3}$ Zhang Baosheng, a leading scholar in China's evidence law reform, found that as of 2008 , no civil law county has a unified set of evidence rules. ${ }^{4}$ Judges in civil law countries generally follow the principle of free evaluation of evidence (自由心证), which is highly discretionary. ${ }^{5}$ Because evidence law had not been a specialized area of law in civil law countries, law schools in these countries usually do not teach evidence law as a separate subject. ${ }^{6}$ On the other hand,

1. Yi Yanyou (易延友), Zhengju Guize de Fadianhua-Meiguo (Lianbang Zhengju Guizey de Zhiding ji Dui Woguo Zhengju Lifa de Qishi (证据规则的法典化一 美国 《联邦证据规则》的制定及对我国证据立法的启示) [The Codification of Evidence Law: The Enactment of the U.S. Federal Rules of Evidence and the Inspiration It Provides to Our Evidence Law Legislation], 26 ZHENGFA LUNTAN (政法论坛) [TRIBUNE OF POLITICAL SCIENCE AND LAW] 80, 80-82 (2008) (China).

2. Wu Danhong (吴丹红), Zhongguo Zhengju Lifa de Lixiang yu Xianshi (中国证据立法的理想与现实) [The Ideal and Reality of Evidence Law Legislation in China], ZHONGGUO MINSHANG FALU WANG (中国民商法律网) [CCCL] [CHINA CIVIL AND COMMERCIAL LAW] (Dec. 7, 2010), http://www.civillaw.com.cn/article/default.asp?id=51456 (last visited Jan. 7, 2013) (China).

3. See Wu Danhong (吴丹红), Zhengju Faxue Yanjiu de Misi-Zai Xifang Yangben he Zhongguo Xianshi Zhijian (证据法学研究的迷思一在西方样本和中国现实之间) [The Myth in Evidence Law Studies: Between Western Samples and the Reality in China], 24 ZHENGFA LUNTAN (ZHONGGUO ZHENGFA DAXUE XUEBAO) (政法论坛（中国政法大学学报) ) [TrIBUNE of Political SCIENCE AND LAW (J. China U. POlitical SCI. L.)] 17, 19 (2006) (Stating that in civil law countries such as Germany and France, evidence-related rules scatter in their codes of civil procedure, criminal procedure, and so forth) (China).

4. Zhang Baosheng (张保生), Zhengju Guize de Jiazhi Jichu he Lilun Tixi (证据规则的价值基础和理论体系) [The Value Basis and Theoretical System of Rules of Evidence], FAXUE YANJIU (法学研究) [CHINESE JOURNAL OF LAW], no. 2, 2008, available at http://mall.cnki.net/magazine/Article/LAWS200802011.htm (last visited Jan. 7, 2013) (China).

5. He Jiahong (何家弘) \& Yao Yongii (姚永吉), Liangda Faxi Zhengju Zhidu Bijiao Lun (两大法系证据制度比较论) IOn the Comparison of the Evidence System in the Two Main Legal Systems], BIJIAO FA YANJIU (比较法研究) [COMPARATIVE LAW STUdIES], no. 4, 2003 , at 55, 64-65 (China).

6. Wu Danhong, supra note 3, at 19. 
almost counter-intuitively, ${ }^{7}$ sophisticated evidence statutes first appeared in common law countries, which had traditionally relied mainly on case law, ${ }^{8}$ a representative example being the U.S. Federal Rules of Evidence (hereinafter the "FRE"). ${ }^{9}$

However, China seems to be headed toward breaking with this tradition. Like in other civil law countries, the code-based legal system in China currently still does not have an evidence statute. Following China's judicial reform in the late twentieth century, unprecedented efforts have been directed toward the study and development of evidence law in China over the past decade, ${ }^{10}$ prompting some scholars to refer to these efforts an "evidence legislation movement" (hereinafter the "Movement"). ${ }^{11}$ The Movement has been fruitful and influential; for instance, it led to the 2012 amendments to the Criminal Procedure Law ${ }^{12}$ and the Civil Procedure Law. ${ }^{13}$

Recent components of the movement include two sets of significant proposed judicial interpretations: The first set, which is named the Uniform Provisions of Evidence of the People's Courts (Proposal for Judicial Interpretations and Drafting Commentary) (hereinafter the "2008 Evidence Provisions"), ${ }^{14}$ resembles the $\mathrm{FRE}^{15}$ in a number of

7. Wu Danhong, supra note 2 (calling this phenomenon an "inexplicable paradox").

8. Yi Yanyou, supra note 1, at 81-82 (discussing the history of enacting evidence statutes in Indiana, the U.K., and the U.S.).

9. E.g., Id. at 80 (commenting that the legislation of evidence law has reached a high level in common law countries; "particularly, the U.S. Federal Rules of Evidence is an outstanding representative"); He Jiahong (何家弘), Zhengju Fa Gongneng zhi Tantao (证据法功能之探讨) [A Discussion of the Function of Evidence Law], FA SHANG YANJIU (法商研究) [STUDIES IN LAW AND BUSINESS], no. 2, 2008, available at http://article.chinalawinfo.com/Article_Detail.asp?ArticleID=52486 (last visited Jan. 7, 2013) (China).

10. Wang Jinxi (王进喜), Zhengju Kexue de Liangge Weidu (证据科学的两个维度) [The Two Dimensions of Evidence Science], 27 ZHENGFA LUNTAN (政法论坛) [TRIBUNE OF POLITICAL SCIENCE AND LAW] 150, 150 (2009) (stating that starting from the beginning of the twenty-first century, the studies of evidence law have become "unprecedentedly prosperous" in China) (China).

11. $I d$.

12. Xingshi Susong Fa (刑事诉讼法) [Criminal Procedure Law] (promulgated by the Standing Comm. Nat'l People's Cong., Mar. 14, 2012, effective Jan. 1, 2013), available at http://www.gov.cn/flfg/2012-03/17/content_2094354.htm (last visited Jan. 7, 2013) [hereinafter 2012 Criminal Procedure].

13. Minshi Susong Fa (民事诉讼法) [Civil Procedure Law] (promulgated by the Standing Comm. Nat'l People's Cong., Aug. 31, 2012, effective Jan. 1, 2013), available at http://www.gov.cn/flfg/2012-09/01/content_2214662.htm (last visited Jan. 7, 2013) [hereinafter 2012 Civil Procedure].

14. RENMin FAYUAN TONGYI ZhengJu GUIDING (SIFA JiESHI JIANYI GAO JI LUNZHENG) (人民法院统一证据规定 (司法解释建议稿及论证)) [UNIFORM PROVISIONS OF EVIDENCE OF THE PEOPLE'S COURTS (PROPOSAL FOR JUDICIAL INTERPRETATIONS AND DRAFTING 
significant aspects; but the second set, which is named Provisions of Litigation Evidence of the People's Courts (Draft for Discussion and Revision) (hereinafter the "2012 Evidence Provisions"), ${ }^{16}$ has lost some of the previous similarities with the FRE. The Supreme People's Court and legal scholars are currently working on a third draft that is scheduled to be published in 2015. ${ }^{17}$

Putting the Movement in a global context, several questions come to mind: How does globalization influence the Movement? How do local factors interact with globalization in the process of this legal transplant?18 How does China's experience with reforming evidence law reflect China's approach to legal transplant in the globalization context?

The authors analyze the latest developments of the Movement as a case study to explore the mechanism of globalization in the setting of a legal transplant. Part I provides a brief summary of the latest developments of the Movement. Part II explores theories related to the relationship between globalization and changes to national law. Part III highlights several aspects in the 2008 Evidence Provisions and the 2012 Evidence Provisions from a comparative law perspective, to look into the interaction between local factors and global factors in the Movement. Part IV concludes that China's approach to its evidence law reform, viewed in a globalization context, reflects a convergence of traditional local elements and modern elements, instead of a duplication of foreign laws.

\section{Development in China's Evidence Legislation Movement}

To date, China's officially promulgated evidence-related rules are spread throughout its statutes of civil procedure, criminal procedure,

COMMENTARY)] (Zhang Baosheng (张保生) ed., 2008) (China) [hereinafter 2008 EvIDENCE PROVISIONS].

15. Federal Rules of Evidence, Pub. L. No. 93-595, 88 Stat. 1926 (1975). The FRE applies to U.S. federal courts, and many state courts in the U.S. follow the same or similar rules. These state courts often look to cases interpreting the FRE in analyzing state rules that are based on the FRE.

16. Renmin Fayuan Susong Zhengju Guiding (Taolun Xiuding Gao) (人民法院诉讼证据规定(讨论修订稿)) [People's Courts Provisions of Evidence in Litigation (Draft for Discussion and Revision)] (Zhang Jun (张军) ed., 2012) (unpublished draft) (on file with the Institute of Evidence Law and Forensic Science at China University of Political Science and Law) (China) [hereinafter 2012 Evidence Provisions].

17. Shen Deyong (沈德咏), Vice-Chief Justice of the Supreme People's Court, Address at the Second Working Conference for the National Social Science Found Key Project "Studies Regarding Provisions of Evidence in Litigation" (Aug. 30, 2013) (transcript on file with CUPL Evidence Institute).

18. See in-depth discussion regarding the concept of "legal transplants" in ALAN WATSON, LEGAL TRANSPLANTS: AN APPROACH TO COMPARATIVE LAW 21 (1974). 
and administrative procedure, as well as the judicial interpretations to these procedural statutes by the Supreme People's Court. ${ }^{19}$ Before 2000, very few evidence rules were available in statutes: Only eight rules in the 1996 Criminal Procedure Law, ${ }^{20}$ six rules in the 1989 Administrative Procedure Law, ${ }^{21}$ and twelve rules in the 1991 Civil Procedure Law. ${ }^{22}$ These rules were mostly simple expressions of general principles. ${ }^{23}$ For example, the 1996 Criminal Procedure Law provides that "collection of evidence using unlawful means, such as intimidation, entrapment, and deceit, is strictly prohibited"; however, the statute did not provide any effective mechanism to carry out this principle (e.g., no consequences attached to its violation). ${ }^{24}$ Also, almost half of the evidence rules in these statutes were either identical or substantially similar. 25

Before the Movement, the concept of "evidence law (证据法学)" was rarely mentioned or studied among China's legal academia. ${ }^{26}$ Although the subject of "evidence (证据学)" did exist, scholars usually associated it with the science of procurement and authentication of evidence, but not

19. Wang Yunying (王云英), Woguo Zhengju Lifa Moshi Tanlun (我国证据立法方式探论) [A Discussion Regarding the Legislative Model for Our Evidence Law], FUJIAN XINGZHENG XUEYUAN XUEBAO (福建行政学院学报) [JOURNAL OF FUJIAN ADMINISTRATION INSTITUTE], no. 4,2009 at 83 (China).

20. Xingshi Susong Fa (刑事诉讼法) [Criminal Procedure Law] (promulgated by the Nat'l People's Cong., Mar. 17, 1996, effective Jan. 1, 1997), art. 42-49, available at http:/www.npc.gov.cn/wxzl/gongbao/2000-12/05/content_5004654.htm (last visited Jan. 7, 2013) (China) [hereinafter 1996 Criminal Procedure Law] (This statute was later amended in 2012).

21. Xingzheng Susong Fa (行政诉公法) [Administrative Procedure Law] (promulgated by the Nat'l People's Cong., Apr. 4, 1989, effective Oct. 1, 1990), art. 31-36, available at http://www.npc.gov.cn/wxzl/gongbao/1989-04/04/content_1481162.htm (last visited Jan. 7, 2013) (China) [hereinafter 1989 Administrative Procedure]. In China, the term "administrative proceedings" refers to actions brought by individuals or entities challenging decisions made by administrative agencies specifically against them (as opposed to challenging policies or regulations applicable to the general public). The Administrative Procedure Law governs the procedure in such proceedings.

22. Minshi Susong Fa (民事诉讼法) [Civil Procedure Law] (promulgated by the Nat'] People's Cong., Apr. 9, 1991, effective Apr. 9, 1991), art. 63-74, available at http://www.lawyee.org/Act/Act_Display.asp?RID=27866 (last visited Jan. 7, 2013) (China) [hereinafter 1991 Civil Procedure] (This statute was later amended in 2007 and in 2012).

23. Wang Yunying, supra note 19 , at 83 .

24. 1996 Criminal Proceure Law, art. 43, supra note 20.

25. Zhang Baosheng, supra note 4 (stating that the repetition rate was about $44.8 \%$ ).

26. Chen Ruihua (陈瑞华), Cong "Zhengju Xue" Zouxiang "Zhengju Fa Xue" (从 “证据学”走向 “证据法学”) [From “Evidence” to “Evidence Law”, FA SHANG YANJIU (法商研究) [STUDIES IN LAW AND BUSINESS], no. 3, 2006, available at http://article.chinalawinfo.com/Article_Detail.asp?ArticleID=47183 (China). 
with legal rules governing the introduction and evaluation of evidence in court. ${ }^{27}$

However, in recent years, enthusiasm among Chinese legal scholars and practitioners for evidence legislation has been unparalleled. ${ }^{28}$ Since 2000 , academic publications about evidence have flourished; law journals emphasizing evidence appeared; academic institutes specializing in evidence emerged in top law schools; and in 2006, China University of Political Science and Law established the nation's first doctoral degree program in evidence law. ${ }^{29}$

The Movement brought about significant changes in the existing procedural law in China, and is getting closer to the goal of enacting a specialized evidence statute:

\section{A. Legislation and Judicial Interpretations}

Since 2002, the Supreme People's Court has promulgated important judicial interpretations specifically addressing evidence issues in criminal actions, ${ }^{30}$ civil actions, ${ }^{31}$ and administrative actions. ${ }^{32}$ In 2007 , the People's Congress amended the Civil Procedure Law. ${ }^{33}$ In 2012, the

27. $I d$.

28. Wang Jinxi, supra note 10 , at 150 .

29. 2008 EVIDENCE PROVISIONS, supra note 14.

30. Guanyu Banli Sixing Anjian Shencha Panduan Zhengju Ruogan Wenti de Guiding (关于办理死刑案件审理判断证据若干问题的规定) [Provisions Concerning Hearing and Judging Evidence in Capital Cases] (promulgated by Sup. People's Ct., Sup. People's Proc., Ministry of Public Security, Ministry of State Security, Ministry of Justice, June 24, 2010, effective July 1, 2010), available at http://www.law-lib.com/law/law_view.asp?id=316882 (last visited Jan. 7, 2013) (China); Guanyu Banli Xingshi Anjian Paichu Feifa Zhengju Ruogan Wenti de Guiding (关于办理刑事案件排除非法证据若干问题的规定) [Provisions Concerning the Exclusion of Unlawfully Obtained Evidence in Criminal Cases] (promulgated by Sup. People's Ct., Sup. People's Proc., Ministry of Public Security, Ministry of State Security, Ministry of Justice, June 24, 2010, effective July 1, 2010), available at $\mathrm{http}: / / \mathrm{www}$.law-lib.com/law/law_view.asp?id=316883 (last visited Jan. 7, 2013) (China) [hereinafter collectively 2010 Provisions of Criminal Evidence].

31. Zuigao Renmin Fayuan Guanyu Minshi Susong Zhengju de Ruogan Guiding (最高人民法院关于民事诉讼证据的若干规定) [Provisions from the Supreme People's Court Concerning Evidence in Civil Litigation] (promulgated by Sup. People's Ct., Dec. 21, 2001, effective Apr. 1, 2002), available at http://www.court.gov.cn/bsfw/sszn/xgft/201004/ t20100426_4533.htm (last visited Jan. 7, 2013) (China).

32. Zuigao Renmin Fayuan Guanyu Xingzheng Susong Zhengju de Ruogan Guiding (最高人民法院关于行政诉讼证据若干问题的规定) [Provisions from the Supreme People's Court Concerning Evidence in Administrative Litigation] (promulgated by Sup. People's Ct., July 24, 2002, effective Oct. 1, 2002), available at http://www.lawlib.com/lawilaw_view.asp?id=40817 (last visited Jan. 7, 2013) (China).

33. Minishi Susong Fa (民事诉讼法) [Civil Procedure Law] (promulgated by the Standing Comm. Nat'l People's Cong., Oct. 28, 2007, effective Apr. 1, 2008), available at 
People's Congress amended the Criminal Procedure Law ${ }^{34}$ and once again amended the Civil Procedure Law. ${ }^{35}$ All three amendments contained significant additions and changes to articles concerning evidence. ${ }^{36}$

The 2012 Criminal Procedure Law, for the first time, included language requiring human rights protection: For example, it granted criminal defendants the right to counsel and the right against selfincrimination-both rights had never been recognized in China's legal system before this amendment. ${ }^{37}$ It also improved rules concerning witness testimony in court, added exclusionary rules and rules concerning witness protection and compensation, and adopted the "beyond a reasonable doubt" standard. ${ }^{38}$ The 2012 Civil Procedure Law improved rules concerning witness testimony in court and authentication; and added a rule regarding witness compensation. ${ }^{39}$

\section{B. Experimental Drafting Projects}

Although the formal legislation process has not yet separated evidence law from traditional procedural statutes, scholars have created various drafts of specialized evidence statutes. ${ }^{40}$ Resulting in significant milestones for the progress of evidence legislation in China, the Supreme People's Court has recently devoted substantial attention to two influential experimental projects, namely, (1) the 2008 Evidence Provisions project, ${ }^{41}$ and (2) the ongoing 2012 Evidence Provisions project.42

The 2008 Evidence Provisions drafting project started in 2006, when the Research Office of the Supreme People's Court delegated the Institute of Evidence Law and Forensic Science at China University of

http://www.china.com.cn/policy/txt/2007-10/29/content_9139262.htm (last visited Jan. 7, 2013) (China) [hereinafter 2007 Civil Procedure].

34. 2012 Criminal Procedure, supra note 12.

35. 2012 Civil Procedure, supra note 13.

36. See 2012 Criminal Procedure, supra note 12; 2012 Civil Procedure, supra note 13; 2007 Civil Procedure, supra note 33.

37. 2012 Criminal Procedure, supra note 12, art. 2, 14, 39, 40.

38. 2012 Criminal Procedure, supra note 12, art. 46-63.

39. 2012 Civil Procedure, supra note 13, art. 63-81.

40. E.g., BI YUQIAN (毕玉谦), ZHONGGUO ZHENGJU FA CAO'AN (JIANYI GAO) (中国证据法草案(建议稿)) [DRAFT OF CHINA EVIDENCE LAW (PROPOSAL)] (2003); CHEN GUANGZHONG (陈光中), ZHONGHUA RENMIN GONGHEGUO XINGSHI ZHENGJU FA ZHUANJIA NIZHI GAO (中华人民共和国刑事诉讼证据法专家拟制稿)[P.R. CHINA CRIMINAL PROCEDURAL EVIDENCE LAW EXPERT DRAFT] (2004); JIANG WEI (江伟), ZHONGGUO ZHENGJU FA CAO'AN (中国证据法草案) [DRAFT OF CHINA EVIDENCE LAW (PROPOSAL)] (2004).

41. 2008 EVIDENCE PROVISIONS, supra note 14

42. 2012 Evidence Provisions, supra note 16. 
Political Science and Law (hereinafter the "CUPL Evidence Institute") to draft a set of judicial interpretations. ${ }^{43}$ The participants of the project contemplated that the 2008 Evidence Provisions would serve as a basis for a comprehensive set of evidence rules in the form of judicial interpretations, which, if approved, would eventually be promulgated by the Supreme People's Court; and at an appropriate time, this set of judicial interpretations could later serve as a blueprint for a formal evidence code. ${ }^{44}$ This contemplated path resembles that of the FRE, which was first adopted by the U.S. Supreme Court in 1972 before it was officially enacted by the U.S. Congress in $1975 .{ }^{45}$ In China, the common law concept of "precedents" does not exist-prior judicial opinions do not bind later cases in any court. Judicial interpretations rendered by the Supreme People's Court are, however, binding authorities for later cases. ${ }^{46}$ To create an entire draft statute based on judicial interpretations is unprecedented in China. Scholars believed that this creative approach would foster experimentation and provide more flexibility, which would allow for later adjustments and ultimately speed up the promulgation of a comprehensive set of evidence rules. 47

In April 2008, the Research Office of the Supreme People's Court delegated the CUPL Evidence Institute to pilot the 2008 Evidence Provisions in seven lower courts, ${ }^{48}$ and the drafting group further amended the draft in 2010 based on feedback from the pilot program. ${ }^{49}$

The 2008 Evidence Provisions consist of seven chapters and contain 172 provisions, ${ }^{50}$ and were, to a significant extent, modeled on the

43. Zhang Jun (张军), Guojia Sheke Jijin Zhongda Xingmu (Di San Pi) Toubiao Shu (国家社科基金重大项目(第三批)投标书) [National Social Science Foundation Key Projects (the Third Batch) Bidding Application] 26 (Sept. 15, 2011) (unpublished bidding application for the 2012 Provisions project) (on file with the CUPL Evidence Institute) (China) [hereinafter 2012 Evidence Provisions Bidding Application].

44. Id. at $37-38$.

45. Historical note of Federal Rules of Evidence, LEGAL INFO. INT., http://www.law.cornell.edu/rules/fre.

46. "Judicial interpretations" are advisory opinions rendered by the Supreme People's Court to interpret statutes. Usually, each advisory opinion either interprets scattered provisions in a statute or advises on a issue that arose in an individual case.

47. 2012 Evidence Provisions Bidding Application, supra note 43, at 38-41.

48. Including four appellate courts and three trial courts: Kunming Intermediate People's Court, Shenzhen Intermediate People's Court, Dongying Intermediate Court, Yanbian Intermediate Court, Haidian People's Court, Dongcheng People's Court, and Shunde People's Court. Id. at 26.

49. Letter from the Supreme People's Court to the CUPL Evidence Institute (Mar. 16, 2012) (on file with CUPL Evidence Institute).

50. Chapter One "General Provisions"; Chapter Two "Categories and Forms of Evidence"; Chapter Three "Exclusion of Evidence and Exceptions"; Chapter Four "Pretrial Exchange of Evidence"; Chapter Five "Presentation of Evidence in Court"; Chapter Six 
FRE. ${ }^{51}$ For example, Section 2 of Chapter I, entitled "Relevance and Admissibility," largely resembles Rules $401-403$ of the FRE governing the relevance of evidence. 52 Section 2 of Chapter III, entitled "Exclusion of Hearsay," largely resembles the hearsay rules in the FRE. ${ }^{33}$ Section 3 of Chapter III, entitled "Exclusion of Character and Propensity Evidence," largely resembles the FRE rules governing character evidence. ${ }^{54}$ Section 4 of Chapter III, entitled "Evidence That Cannot Be Used to Provide Fault or Liability," largely resembles the FRE rules regarding subsequent remedial measures (FRE 407), compromise offers and negotiations (FRE 408), offers to pay medical or similar expenses (FRE 409), and plea-related statements (FRE 410). ${ }^{55}$ One can also find traces of the FRE in other parts of the 2008 Evidence Provisions; for instance, Article 68 of the 2008 Evidence Provisions describes an attorney-client privilege that drew inspiration from Rule 502 of the FRE. 56

Concepts such as relevance, admissibility, hearsay, and privilege did not exist in China's legal system prior to the 2008 Evidence Provisions project. Introducing these concepts was an attempt to inject into the system a new way of thinking and a more systematic methodology to analyze evidence issues.

Beyond heavily referencing the FRE, the drafting notes in the 2008 Evidence Provisions also cite to existing sources of evidence rules in China, ${ }^{57}$ and to evidence rules in other jurisdictions such as Italy, Germany, France, Russia, Japan, India, Australia, the Philippines, and Canada. ${ }^{58}$

"Collection and Protection of Evidence by Court"); Chapter Seven "Proof." 2008 EvidENCE PROVISIONS, supra note 14.

51. See Email from Zhang Baosheng (张保生), Dean of the CUPL Evidence Institute and leading expert of the 2008 Evidence Provisions project, to Wang Zhuhao (汪诸蒙) (Nov. 15, 2012, 12:18 AM CST) (on file with authors) ("[The 2008 Evidence Provisions] was mainly a product of sinicizing the achievement of the U.S. evidence law."). Zhang Baosheng is the Lead Expert of the 2008 Evidence Provisions' drafting committee.

52. Compare 2008 Evidence Provisions, supra note 14, art. 11-13 with FED. R. Evid. 401-403.

53. Compare 2008 Evidence PROvisions, supra note 14, art. 28-32 with FED. R. Evid. $801,802,803,804,807$.

54. Compare 2008 Evidence Provisions, supra note 14, art. 33-34 with FED. R. Evid. 404.

55. Compare 2008 Evidence Provisions, supra note 14, art. 35-38 with FED. R. Evid. 407-410.

56. Compare 2008 EVIDEnCe Provisions, supra note 14, art. 68 with FED. R. EVID. 502. See infra Part III.C. for detailed discussion.

57. Including procedural statutes passed by the People's Congress and judicial interpretations promulgated by all levels of courts in China.

58. 2008 EVIDENCE PROVISIONS, supra note 14. 
The ongoing 2012 Evidence Provisions project is led by the Supreme People's Court.59 Zhang Baosheng, the Lead Expert of the 2008 Evidence Provisions, is also an important member of the 2012 Evidence Provisions drafting committee.60 The goal of this project is similar to that of the 2008 Evidence Provisions. ${ }^{61}$ The 2012 Evidence Provisions consist of nine chapters and include 179 provisions. ${ }^{62}$ While the 2012 Evidence Provisions maintain some of the new concepts that the 2008 Evidence Provisions had borrowed from the FRE (e.g., relevance, privilege, exclusion of illegally obtained evidence in criminal cases), ${ }^{63}$ the newer provisions were mainly based on existing statutes and judicial interpretations in China ${ }^{64}$ Notably, the drafting notes for the 2012 Evidence Provisions cite only to sources of law in China. The text of the 2012 provisions reads much less like the FRE, and appears to have incorporated more local factors adapting to China's social and legal custom. 65

The participants of the 2012 Evidence Provisions project aim to publish a third draft in 2015.66 In August 2013, a conference was held for this project in Anhui Province.67 In his address during this conference, Shen Deyong, the Vice-Chief Justice of the Supreme People's Court and the lead expert of the project, emphasized that the $2015 \mathrm{draft}$ should focus on reflecting the characteristics of China's society and legal system, while drawing inspiration from external sources including evidence rules in various common law countries, civil law countries, and international treaties. 68

59. Letter from the Supreme People's Court to the CUPL Evidence Institute, supra note 49; 2012 Evidence Provisions Bidding Application, supra note 43, at 3.

60. 2012 Evidence Provisions Bidding Application, supra note 43, at 3.

61. Id. at 46 .

62. Chapter One "General Provisions"; Chapter Two "Exclusion of Evidence and Exceptions"; Chapter Three "Pretrial Exchange of Evidence"; Chapter Four "Authentication"; Chapter Five "Collection and Protection of Evidence by Court"; Chapter Six "Burden of Proof and Standard of Proof"; Chapter Seven "Presentation of Evidence in Court"; Chapter Eight "Confrontation"; Chapter Nine "Evaluating the Weight of Evidence." 2012 Evidence Provisions, supra note 16.

63. 2012 Evidence Provisions, supra note 16.

64. Id.; see also email from Zhang Baosheng to Wang Zhuhao, supra note 51.

65. See discussion of examples infra Part III.

66. Shen Deyong (沈德咏), supra note 17.

67. Id.

68. Id. 


\section{THEORETICAL FRAMEWORK OF GLOBALIZATION APPLICABLE TO LEGAL TRANSPLANTS}

Legal transplants involve moving a rule or a system of law from one country to another, or from one people to another. ${ }^{69}$ They have been common since the earliest recorded history. ${ }^{70}$ In the contemporary world, the reach of globalization has spanned beyond the movement of goods, services, and capital. ${ }^{71}$ Globalization now encompasses the flow of ideas around the world, and increasingly influences the legal and social institutions in individual nations. ${ }^{72}$ Legal transplants, therefore, inevitably interact with globalization. However, when analyzing legal or cultural changes, scholars have different understandings of globalization.

\section{A. Convergence or Not?}

Whether globalization is leading to a worldwide convergence in law is the subject of much debate. ${ }^{73}$ Some scholars have viewed globalization as a process of convergence ${ }^{74}$ featuring homogenization and deterritorialization, ${ }^{75}$ which dilute nationalism and local identities. ${ }^{76}$

Other scholars have observed the "limits" of globalization, ${ }^{77}$ warning that we should not exaggerate the extent of globalization. ${ }^{78}$ For example, in their study of bankruptcy law transplants in Indonesia, Korea, and China, Terence C. Halliday and Bruce G. Carruthers found

69. WATSON, supra note 18 , at 21 .

70. Id.

71. Terence C. Halliday \& Bruce G. Carruthers, Bankrupt: Global lawmaking AND SYSTEMIC FinANCIAL CRISIS, at xii (2009).

72. $I d$.

73. Id. at xxi ("The issue of convergence has become something of a set piece in discussions of globalization ....").

74. See id. at xxi ("[Early arguments stat[ed] that globalization was going to lead to rapid convergence among ... public policies.").

75. See From Here to Diversity: Globalization and InTERcultural Dialogues, at $\mathrm{xxv}$ (Clara Sarmento ed. 2010) (describing homogenization and deterritorialization as two of the features of cultural transformations in the contemporary world).

76. Mălina Ciocea, Paul Dbrescu \& Diana Cismaru, Changing Patterns of Consumerism in Young People in Romania, in From HeRe to Diversity: Globalization AND INTERCUlTURAL Dialogues, supra note 75, at 177 ("Global flows pressure local identities into playing second fiddle....").

77. HALLIDAY \& CARRUTHERS, supra note 71, at 427 ("In view of the limits revealed by a recursive approach to globalization of law and markets, we take issue with strong theories of globalization.").

78. Id. at xxi ("Simplistic convergence arguments became something of a dead horse to be ritually flogged while noting the limits of globalization and criticizing exaggerated claims about its effects."). 
that, although.." "there has been significant convergence in the formulation of. global norms for corporate bankruptcy law,... [c]onsiderable variation occurs across nations, time, and jurisdictions"; and that "[]ocal rules are changed by their encounter with the global, but they do not mirror or reproduce it slavishly."79 To explain why "strict conformity [of global norms] among nation-states is found nowhere," 80 scholars have resorted to theories such as the recursivity model, ${ }^{81}$ institutional inertia, ${ }^{82}$ the psychological value of territorial identity, ${ }^{83}$ and so forth. A common trait of these theories is that they all contend that local factors, such as local culture, sentiment, or institutional tradition, act as barriers against a complete global integration, and in that sense, "limit" globalization.

Both views indicate that many scholars, explicitly or implicitly, saw globalization as a process leading to a complete integration and convergence. ${ }^{84}$ However, Alan Watson believed that, in the context of legal transplants, perhaps it is unnecessary and unreasonable to expect a complete unification in most areas of law. 85 Thus, an alternative interpretation of globalization may be better suited for analyses in the context of legal transplants-for example, the modernization theory. ${ }^{86}$

\section{B. Modernization}

Some scholars argued that globalization is a process of modernization. 87 In their eyes, Globalization is an "evolutionary

79. Id. at 400 .

80. Id.

81. Id. at 365; see also Sida Liu \& Terence C. Halliday, Recursivity in Legal Change: Lawyers and Reforms of China's Criminal Procedure Law, 34 LAW \& SOC. INQUIRY 911, 913-14 (2009).

82. Randall Peerenboom, What Have We Learned About Law and Development?: Describing, Predicting, and Assessing Legal Reforms in China, 27 MICH. J. INT'L L. 823, 847 (2006).

83. WATSON, supra note 18, at 101 (concluding that variation in transplanted law is more bout "the psychological value of having one's own legal system").

84. As discussed above, scholars holding the convergence argument explicitly interpreted globalization as a process of integration and convergence. Scholars who observed the "limits" of globalization implicitly adopted the same meaning of the term "globalization"--by describing phenomena short of a complete worldwide convergence as the "limits" of globalization.

85. WATSON, supra note 18 , at 100 ("Obviously a complete legal union is neither possible nor desirable"; but adding a footnote 14, which stated that commercial law is and exception).

86. See infra Part II.B.

87. See Ciocea, Dbrescu \& Cismaru, supra note 76, at 187 ('Most probably, the most fruitful analysis will be that of promoting globalization (including cultural globalization) as modernization."); see also David Nelken, Signaling Conformity: Changing Norms in 
process," 88 and modernity "involves reflexivity, departing from tradition, changing the structure of social relations"; 89 it follows-that "[m]odernity is inherently globalizing." ${ }^{0}$ Watson's analogy in Legal Transplants: An Approach to Comparative Law is particularly helpful in explaining why interpreting globalization to be synonymous with modernization would be proper in the context of legal transplants:

[L]aw like technology is very much the fruit of human experience. Just as very few people have thought of the wheel yet once invented its advantages can be seen and the wheel used by many, so important legal rules are invented by a few people or nations, and once invented their value can readily be appreciated, and the rules themselves adopted for the needs of many nations. ${ }^{91}$

In Waston's analogy, the reason why the idea of the wheel spreads globally is that it serves a need that all members of the global society share, and represents a value that all members of the global society recognize; it is human progress. The process of taking the idea of the wheel and developing it into different forms is modernization.

The latest developments in China's evidence legislation movement are reflective of such a modernization process. Influenced by the global legal culture, ${ }^{92}$ drafters of the 2008 and 2012 Evidence Provisions took inspiration from other legal systems, injected new elements reflecting human progress into the Chinese legal system, and adapted these elements to local traditions and characteristics.

Japan and China, 27 MICH. J. INT'L L. 933, 966 (2006) (implying that the phrases "global legal culture" and "modern legal culture" could be used interchangeably).

88. Maria de Deus Manso, Portuguese Expansion and the Construction of Globalization, in From HERE TO DIVERSITY: GLOBALIZATION AND INTERCULTURAL DIALOGUES, supra note 75 , at 282 .

89. Ciocea, Dbrescu \& Cismaru, supra note 76, at 176.

90. Id. (quoting ANTHONY GIDDENS, THE CONSEQUENCE OF MODERNITY 63 (1990)).

91. WATSON, supra note 18 , at 100.

92. The concept of "global legal culture" has been mentioned, but its meaning varies in different academic discussions. See, e.g., Charles H. Koch, Jr., Envisioning A Global Legal Culture, 25 MICH. J. INT'L L. 1, 2 (2003); Russell Menyhart, Changing Identities and Changing Law: Possibilities for A Global Legal Culture, 10 IND. J. Global Legal STUD. 157,159 (2003). For the purpose of this note, it is defined as a collection of legal elements that foster globally recognized values and represent progress of human society. 


\section{ANALYSIS OF THE 2008 EVIDENCE PROVISIONS AND THE 2012 EVIDENCE PROVISIONS}

In the field of evidence law, the need to ascertain the truth is universally shared; and the values of fairness, efficiency, and human rights are globally recognized. ${ }^{93}$ The 2008 Evidence Provisions and the 2012 Evidence Provisions both adopt elements in U.S. evidence law that foster these values in the legal transplant process, but each showed variations on some levels. The following concepts had not existed in the Chinese legal system before the Movement.

\section{A. Establishing an Evidence Rule System}

The idea of systemizing evidence law and providing more technical details, inspired by the FRE, reflects the values of fairness and efficiency. A rational and logical evidence rule system will help limit judges' discretionary powers, and hence increase consistency and reduce uncertainty. This is especially important in developing countries such as China, because "uncertainty related to the application of the law-due to discretionary power and the inefficient administration of justice-is increasing transaction costs and fostering corruption." 94

A unified and specialized statute for evidence is unprecedented in China. Some Chinese scholars opposed the idea of enacting an evidence statute in China; their strongest argument is that China's court system is separated into specialized divisions (e.g., civil and commercial court, criminal court, administrative court, and so forth), a feature that U.S. courts do not share. ${ }^{95}$ However, given the striking overlap among evidence rules scattered in the various procedural statutes, as discussed in Part I above, perhaps the contention that countries in the civil law system cannot have an evidence statute results from academic inertia or prejudice that fails to see the necessity to modernize the system. ${ }^{96}$

93. Compare Zhangbaosheng, supra note 4, with FED. R. EvD. 102.

94. EDGARDo BusCAGLIA \&WILLAM RATLIFF, LAW AND ECONOMICS IN DEVELOPING COUNTRIES 6 (2000).

95. Zhang Baosheng, supra note 4.

96. See Zhang Baosheng (张保生), Man Yunlong (满运龙) \& Long Weiqiu (龙卫球), Meiguo Zhengju Fa de Jiazhi Jichu (美国证据法的价值基础) (The Value Basis of American Evidence Law), ZHONGGUO ZHENGFA DAXUE XUEBAO) (中国政法大学学报) [J. CHINA U. POLITICAL SCI. L.], no. 6, 2009, at 51, 52 (discussion regarding a German scholar who opposed China's plan to enact a specialized evidence statute and reasoned that it would be against the tradition in civil law countries). 


\section{B. Exclusionary Rules}

The exclusionary rules serve to protect individual rights. The 2008 Evidence Provisions have four provisions pertaining to the exclusion of illegally obtained evidence in criminal cases ${ }^{97}$, and the 2012 Evidence Provisions have eleven provisions regarding exclusionary rules ${ }^{98}$. Both Provisions prohibit forced self-incrimination. ${ }^{99}$ In fact, the newly amended 2012 Criminal Procedure Law has already added similar rules for the first time in a formal statute in China. ${ }^{100}$

In the past, due to heavy reliance on confession in criminal prosecutions, torture and forced confession were prevalent in criminal cases and led to a number of wrongful convictions. ${ }^{101}$ During the past decade, Chinese scholars and practitioners devoted increasing attention to China's international obligation to protect the human rights of the accused, as expressed in international treaties. ${ }^{102}$ Gradually, a consensus was formed that criminal defendants have human rights, and exclusionary rules are necessary to ensure these rights. However, this consensus did not come easily for the public in China.

In a high profile case occurring about ten years ago, a lower court initially found an accused mafia leader not guilty because the prosecution's key evidence was found to be a forced confession-namely, an admission of guilt that the police obtained through torturing the accused. ${ }^{103}$ Massive media coverage of this decision stirred up widespread criticism from the public-they believed that a mafia leader

97. 2008 Evidence Provisions, supra note 14, art. 22, 23, 24, 27.

98. 2012 Evidence Provisions, supra note 16, art. 21-31.

99. 2008 EVIDENCE Provisions, supra note 14, art. 128; 2012 Evidence Provisions, supra note 16 , art. 72 .

100. 2012 Criminal Procedure, supra note 12, art. 54-58.

101. Minzhu Fazhi: Gouzhu Yuanli Yuan'an de "Liangdao Fangxian" (民主法制: 构筑远离哌案的“两道防线”) [Democracy and Law: Building "Two Defensive Lines" to Avoid Wrongful Convictions], PEOPLE (人民网) (Apr. 19, 2005, 19:05), http://npc.people.com.cn/GB/14840/3333260.html (China).

102. E.g., Zuo Weimin (左卫民) \& Liu Tao (刘涛), Zhengiu Zhidu Guojixing Zhunze yu Zhongguo Xingshi Zhengju Zhidu Gaige (证据制度因际性准则与中国刑事证据制度改革) [International Principles of Evidence and China's Reform of Evidence Rules in Criminal Cases], ARTICLE.CHINALAWINFO.COM (北大法律网法学在线), http://article.chinalawinfo.com/ Article_Detail.asp?ArticleId=21725 (last visited Dec. 17, 2012) (China); Chen Zhanjun (陈占军), Cong Renquan Gongyue Kan Xingshi Susongfa zhi Quexian (从人权公约看形争诉讼法之缺陷) [International Human Rights Treaties and Defects of Criminal Procedural Law], CRIMINALLAWYERCN.COM (中国刑事律师网) (Nov. 18, 2005), http://www.southlawyer.net/homepage/21/20051118110548570720.html (China).

103. Zhendong Yishi de "Liu Youg An" Shenpan: Falv yu Minyi (震动一时的“刘涌案”审判: 法律与民意) [The Once-Notorious “Liu Yong Case”: Law and Public Opinion], SOHU.COM (搜狐新闻) (Apr. 25, 2008), http://news.sohu.com/20080425/ n256520477.shtml (China). 
deserved nothing short of a death sentence. ${ }^{104}$ The Supreme People's Court, faced with public pressure, reheard the case, reversed the lower courts' ruling, and sentenced the defendant to death. ${ }^{105}$ The defense attorney suffered intense media and public attacks; even some of his fellow attorneys despised him for zealously representing his client and, in their view, failing to "represent justice."106 At the time, although China had started reforming its criminal procedure law, the local culture did not accept the idea that a "bad guy" may have legitimate rights that deserve protection. During more recent years, under the influence of global legal culture, public opinion in China has become more receptive to the exclusionary rules. ${ }^{107}$ This eventual change in perception among the Chinese people exemplifies that when local culture is at odds with globally recognized values, the more frequent exchanges of ideas around the world may help modernize the local culture and facilitate changes in the local law.

The 2008 Evidence Provisions and the 2012 Evidence Provisions both exclude unlawfully obtained evidence in not only criminal cases, but also civil and administrative cases. ${ }^{108}$ This may be an effort to further emphasize individual rights in China's legal reform.

\section{Privilege and Confidentiality}

Privilege and confidentiality rules protect individual rights by ensuring free communications within a relationship of trust and confidence. Although not previously recognized in the Chinese legal system, the concept of privilege and confidentiality were recently introduced into the system through legislation. In 2007, the Standing Committee of the People's Congress added a confidentiality rule in the Lawyer Law, which states, "An attorney shall keep confidential state secrets, trade secrets, and clients' privacy that she learned during the representation; an attorney shall keep confidential circumstances and information, the disclosure of which her client or other people do not desire."109 The 2012 Criminal Procedure Law added an article providing

104. Id.

105. Id.

106. $I d$.

107. See Liu Wei (刘炜), “Xingxun Bigong” Zhengju Paichu Lu (刑讯逼供证据排除录) $[A$ Case about Excluding Forced Confession], www.MzYFz.COM (民主与法制网) (June 7, 2012), http://www.mzyfz.com/cms/benwangzhuanfang/xinwenzhongxin/zuixinbaodao/html/1040/2 012-05-07/content-366409.html (China).

108. 2008 Evidence Provisions, supra note 14, art. 25; 2012 Evidence Provisions, supra note 16 , art. 32 .

109. Lushi Fa (律师法) [Lawyer Law] (promulgated by the Standing Comm. Nat'l People's Cong., Oct. 28, 2007, effective June 1, 2008), art. 38, available at http://www.law- 
that "a defense attorney has the right to keep confidential circumstances and information regarding the client that the defense attorney learned during the representation." 110

In U.S. law, the concept of "privilege" differs from that of "confidentiality." The attorney-client privilege provided in the FRE protects confidential communications between an attorney and his client from being disclosed to in a judicial or other proceeding, "in which a lawyer may be called as a witness or otherwise required to produce evidence concerning a client." 111 The goal is to allow the client to freely communicate with her attorney for legal advice without fearing that such communications may prejudice the client in the future. The client, rather than the attorney, is the holder of the privilege-namely, the client is the person who is authorized to claim the privilege. Also, such privilege can be considered waived, sometimes involuntarily or inadvertently, because of partial disclosure of information. ${ }^{112}$ Different from the attorney-client privilege rule, the confidentiality rule provided in the ABA Model Rules of Professional Conduct, "applies in situations other than those where evidence is sought from the lawyer through compulsion of law."113 The confidentiality rule protects not only matters communicated in confidence by the client, but also "all information relating to the representation, whatever its source." Confidentiality may not be waived unless the client gives informed consent or otherwise required by the law or the ethics rules. ${ }^{114}$

Both the 2008 Evidence Provisions and the 2012 Evidence Provisions include rules that are labeled "attorney-client privilege." The scope of the privilege is quite different between the two documents. However, neither document seems to distinguish "privilege" from "confidentiality."

Although both Provisions have articles entitled "attorney-client privilege," the 2008 Evidence Provisions protect "confidential communications" between an attorney and his client, ${ }^{115}$ while the 2012 Evidence Provisions protect "circumstances and information regarding the client that the attorney learned during the representation." 116 The language in the 2012 Evidence Provisions reads more like the

lib.com/law/law_view.asp?id=223162 (last visited Jan. 7, 2013) (the law governing attorneys' professional responsibilities in China).

110. 2012 Criminal Procedure, supra note 12, art. 46.

111. FED. R. EVID. 502; MODEL RULES OF PROF'L CONDUCT R. $1.6 \mathrm{cmt}$. (1983).

112. FED. R. EvID. 502.

113. Model Rules of Prof'L ConduCt R. $1.6 \mathrm{cmt}$. (1983).

114. Id.

115. 2008 EVIDENCE PROVISIONS, supra note 14, art. 68.

116. 2012 Evidence Provisions, supra note 16, art. 97. 
confidentiality rule in the ABA Model Rules of Professional Conduct, ${ }^{117}$ while the 2008 Evidence Provisions adopt the attorney-client privilege language of the FRE. ${ }^{118}$ As discussed above, the confidentiality concept in U.S. law protects more information than the privilege concept in U.S. law; therefore, the 2012 Evidence Provisions provide a broader scope of protection than provided by the 2008 Evidence Provisions. Interestingly, both Provisions refer to the attorney-client privilege as an attorney's right, contrary to the common law belief that such privilege is held by the client. Neither document provides rules regarding waiver of privileges or confidentiality.

Both Provisions provide an "immediate relative privilege," which is a variation of the marital communication privilege found in U.S. law. In addition to protecting the relationship between spouses, the 2008 Evidence Provisions and the 2012 Evidence Provisions extend such a privilege to parents and children.119 The protected scope of this immediate relative privilege is not limited to "communications" between the witness and the defendant-rather, both Provisions describe the immediate relative privilege as an absolute immunity to testify against the protected relative. ${ }^{120}$ Therefore, it is much broader than that of the U.S. marital privilege. The traditional culture in China features an extremely close and trusting relationship between parents and children, often even to a greater extent than a spousal relationship. The creation of such an "immediate relative privilege" is in line with the value that privilege rules protect, and it reflects the reality and characteristics of China's society.

In addition, the 2008 Evidence Provisions contain psychiatrist's privilege, judge's privilege, secret agent's privilege, and so forth. ${ }^{121}$ In contrast, the 2012 Evidence Provisions does not adopt these privileges. ${ }^{122}$

117. Compare 2012 Evidence Provisions, supra note 16, art. 97 with MODEL RULES OF PROF́l CONDUCT R. 1.6 (2012).

118. Compare 2008 EVIDEnCE Provisions, supra note 14, art. 68 with FED. R. EvID. $502(\mathrm{~g})(1)$

119. 2008 Evidence Provisions, supra note 14, art. 70; 2012 Evidence Provisions, supra note 16 , art. 98 .

120. Id.

121. 2008 Evidence Provisions; supra note 14, art. 63-71.

122. See generally 2012 Evidence Provisions, supra note 16. 


\section{Relevance and Admissibility}

The concepts of relevance and admissibility represent a logical, ${ }^{123}$ coherent, and standardized terminology system that is recognized not only in common law, but also in international documents. ${ }^{124}$ To use such a terminology system serves the values of efficiency and fairness by ensuring consistency and reducing randomness in evaluating evidence. ${ }^{125}$

Both the 2008 Evidence Provisions and the 2012 Evidence Provisions adopt the concepts of relevance and admissibility in various provisions. The relevance and admissibility rules found in the 2008 Evidence Provisions resemble their FRE counterparts. ${ }^{26}$ The 2012 Evidence Provisions combine the relevance and admissibility requirements into one rule; it stripped the balancing test found in the FRE, which weighs probative value against prejudice and waste of time, ${ }^{127}$ and replaced it with language requiring a holistic analysis of all evidence. ${ }^{128}$. This might be an attempt to streamline the rule system.

In addition, both Provisions also adopt rules limiting the admissibility of certain types of evidence for a specific purpose-namely, the equivalent of FRE rules regarding subsequent remedial measures and compromise offers. ${ }^{129}$ In China, an "administrative proceeding" is an action brought by a private party before a court to challenge a decision made by an administrative agency specifically against the private party. As will be discussed below, in such an action, the government bears the burden to prove that its action was legitimate. Interestingly, both Provisions limit the use of certain evidence by the government to prove

123. Zhang Baosheng, supra note 4 (referring to relevance as the "logical thread" of evidence law).

124. See E.g., UNCITRAL Model Law on International Commercial Arbitration, article 19(2) (2006), available at http://www.uncitral.org/uncitral/en/uncitral_texts/arbitration/ 1985Model_arbitration.html.

125. See He Jiahong (何家弘), Lun Falv Yuyan de Tongyi he Guifan (论法律语言的统一和规范) [The Unification and Accuracy of Legal Language], ZHONGGUO RENMIN DAXUE XUEBAO (中国人民大学学报) [J. RENMIN U. CHINA], no. 1, 2009, available at http://article.chinalawinfo.com/Article_Detail.asp?ArticleID=52821 (last visited Jan. 7, 2013) (China) (stressing the importance of consistency and accuracy in legal terminology).

126. Compare 2008 EVIDENCE PROVISIONS, supra note 14, art. 11-13 with FED. R. EVID 401-403.

127. FED. R. EVID. 403.

128. Compare 2012 Evidence Provisions, supra note 16, art. 7 with FED. R. EvID. 403.

129. Compare 2008 Evidence Provisions, supra note 14, art. 35-37 with Fed. R. Evid 407-409; Compare 2012 Evidence Provisions, supra note 16, art. 34-35 with FED. R. EVID 401.403. 
the legitimacy of a state action in an administrative proceeding. ${ }^{130}$ For example, the government defendant in an administrative proceeding, in satisfying its burden to prove that its action against the private plaintiff was legitimate, cannot use evidence acquired after the challenged administrative decision or evidence acquired through depriving private parties' legally protected rights. ${ }^{131}$ This creative element reveals the drafters' intention to balance the powers between the two parties in an administrative action-a private party versus the government-by supplementing the protective measures afforded to the private party, who would otherwise be disadvantaged.

\section{E. Standard of Proof}

The concept of the standard of proof is alien to the Chinese legal system. Prior to the 2012 amendments to the Criminal Procedure Law, which mentioned the phrase "beyond a reasonable doubt,"132 no statute had provided for the standard of proof.

The 2008 Evidence Provisions and the 2012 Evidence Provisions both provide for standards of proof in criminal proceedings, civil proceedings, and administrative proceedings.

For criminal proceedings, both Provisions adopt the "beyond a reasonable doubt" standard.133 For civil proceedings, neither document borrowed the "preponderance of the evidence" standard from common law. Rather, the 2008 Evidence Provisions adopt a "high probability" standard for civil cases, ${ }^{134}$ whereas the 2012 Evidence Provisions do not provide a clear standard of proof for civil proceedings. ${ }^{135}$ For administrative proceedings, ${ }^{136}$. both the 2008 Evidence Provisions and

130. 2008 Evidence Provisions, supra note 14, art. 26; 2012 Evidence Provisions, supra note 16 , art. 33 .

131. 2008 Evidence Provisions, supra note 14, art. 26; 2012 Evidence Provisions, supra note 16 , art. 33 .

132. 2012 Criminal Procedure, supra note 12, art. 53(3).

133. 2008 Evidence Provisions, supra note 14, art. 130; 2012 Evidence Provisions, supra note 16 , art. 74.

134. 2008 EVIDENCE PROVISIONS, supra note 14, art. 133.

135. 2012 Evidence Provisions, supra note 16, art. 80 (providing, "When both parties produce conflicting evidence regarding the same fact but neither has enough basis to rebut the other, the court shall look at the circumstances of the case, decide whether one side's evidence carries significantly more weight than the other side's, and confirm the evidence that carries more weight."). This provision provides for a method of weighing evidence rather than an actual standard of proof. See discussion of "weight of evidence" infra Part III.F.3.

136. In China, an "administrative proceeding" is an action brought by a private party before the court to challenge a decision made by an administrative agency specifically 
the 2012 Evidence Provisions require the administrative agency (i.e., the defendant) to prove "beyond a reasonable doubt" the legality of its administrative decisions in question; however, the 2008 Evidence Provisions allow the "high probability" standard under certain exceptions, whereas the 2012 Evidence Provisions do not provide any exceptions. ${ }^{137}$ The heightened standard for administrative proceedings, again, shows an effort to balance the powers between the two parties in an administrative action. This is in line with the values of fairness and individual rights.

\section{F. Hearsay}

The 2008 Evidence Provisions adopt the concept of hearsay and used language substantially similar to FRE rules in its hearsay section. ${ }^{138}$ However, in the 2012 Evidence Provisions, the drafters chose to leave out the hearsay rules. ${ }^{139}$ The reason is probably multi-fold:

\section{Practical Considerations}

In China, witnesses are often extremely reluctant to testify in court. ${ }^{140}$ Although there may be other factors at play, scholars believed that this reluctance is mainly attributable to the Chinese cultural tradition of avoiding public confrontation. ${ }^{141}$ According to several surveys conducted in 2005 to 2007, the average rate of witness appearance in court was consistently less than 1\%.142 Although the 2012 Evidence Provisions attempt to encourage witness appearances in court by providing mechanisms to protect the privacy, identity, and physical safety of the witness, low appearance rates remain a problem.

In contrast to the U.S. legal system, where courts may hold witnesses in contempt of court when they fail to comply with

against the private party. In such an action, the government bears the burden to prove that its action was legitimate.

137. 2008 Evidence Provisions, supra note 14, art. 147-148; 2012 Evidence Provisions, supra note 16 , art. 85 .

138. Compare 2008 Evidence Provisions, supra note 14, art. 28-32 with FED. R. EvID 801-807.

139. See generally 2012 Evidence Provisions, supra note 16.

140. Paul J. Shmidt, A Review of China's New Civil Evidence Law, 12 PAC. RIM L. \& POL'Y J. 291, 303 (2003).

141. Id.

142. Zhang Zhong (张中), Guanyu "Renmin Fayuan Tongyi Zhengju Guiding" Diaoyan Baogao (关于 《人民法院统一证据规定》调研报告) [Investigation and Research Report Regarding the People's Court Uniform Provisions of Evidence], in ZHENGJU LILUN YU KEXUE (证据理论与科学) [EVIDENCE LAW THEORIES AND FORENSIC SCIENCE] 99, 112 (2007). 
summonses, the current Chinese legal system does not have rules to hold the witnesses accountable when they fail to appear in court.

\section{Judges' Dual Role}

In the U.S. légal system, distinctions are drawn between matters of fact and matters of law. Matters of law are exclusively decided by judges, whereas matters of facts are decided by juries in jury trials (or by judges in bench trials). Under U.S. rules of evidence, although hearsay evidence is generally excluded from consideration in the factfinding process, judges are allowed to consider hearsay for certain issues such as admissibility-because admissibility is considered a matter of law. ${ }^{143}$ Also, the U.S. hearsay rules presume exclusion first, and then provide numerous exceptions that effectively allow admission of most hearsay evidence for the fact-finding process. However, in the Chinese legal system, no jury exists, and no distinctions are drawn between matters of fact and matters of law. Judges are both finders of fact and deciders of legal issues. Thus, it may be less confusing and more efficient to use an alternative mechanism to manage the reliability of evidence in the Chinese legal system.

\section{A Weight of Evidence System}

As an alternative to the approach taken in the U.S., the 2012 Evidence Provisions provide a weight of evidence system that ranks the weight of different types of evidence and compares related evidence against each other. ${ }^{144}$ Instead of completely excluding certain evidence whose veracity cannot be ascertained, this system requires corroborating evidence for suspicious evidence to be admissible. This would allow more opportunities for judges to consider the evidence in a holistic manner, which would foster the values of fairness and efficiency.

\section{CONCLUSION}

The 2008 Evidence Provisions and the 2012 Evidence Provisions reflect a mixture of borrowed law and local variations. The borrowed elements and the variations both embraced the values of fairness, efficiency, and human rights shared in the global legal culture. The 2012 Evidence Provisions contain a number of local features that dramatically differ from the American evidence rules, such as judicial

143. FED. R. EVID. 104(a).

144. E.g., 2012 Evidence Provisions, supra note 16, art. 169, 170. 
evidence collection and investigation, judicial authentication, concurrent confrontation.

Whether the 2012 Evidence Provisions project will generate a third draft in 2015 as planned, whether one of the experimental drafts actually will be promulgated by the Supreme People's Court, and whether one of the drafts will eventually become China's first evidence statute, remain to be seen. Regardless of whether enacted into law, the experimental drafting processes undertaken in the 2008 Evidence Provisions and in the 2012 Evidence Provisions are steps along a trail to legal modernity: China is reshaping its identity in the global legal society as a participant that strives to achieve fairness, efficiency, and better protection for individual rights; this experience demonstrates a kind of legal transplant that is an evolutionary process re-creating the local culture by incorporating modern values in a way unique to the people.

China's new development in establishing its evidence law system represents a milestone in its ongoing effort to modernize its legal system. Moving forward, it is logical to expect that the Chinese legal system will further embrace the global legal culture in not only the design of procedural rules, but also judicial independence, and the way lawyers practice law. This modernization process will likely shape China's new identity in the global legal society, adding to the diversity of the modern legal landscape. 
